\title{
KORELASI PERAN HAKAM (JURU DAMAI) DENGAN MEDIATOR DALAM PROSES MEDIASI PERKARA PERCERAIAN DI PENGADILAN AGAMA
}

\author{
SUWARDI \\ suwardi531@gmail.com \\ Dosen Fakutas Hukum Universitas Ekasakti
}

\begin{abstract}
: mediation that is carried out by the mediator in a juridical manner must be carried out before the main examination of the case, and if it is not implemented it will result in the decision being null and void (Supreme Court Regulation Number 1 of 2008). Meanwhile, the legal process that originates from each family party, juridically it is an initiative of the panel of judges to implement (Law on Religious Courts), because in the existing regulations it is stated with the phrase "can", which is based on an interim decision by the panel of judges. those who examine, in fact, in practice, the role of Hakam in divorce proceedings in religious courts is no longer relevant and implemented, because his function has been replaced by a mediator as required by a Supreme Court Regulation, and the litigants tend to be determined to separate.
\end{abstract}

Keywords: Hakam, Mediator, Mediation, Divorce, Religious Courts.

\begin{abstract}
Absttrak: mediasi yang dilakukan oleh mediator secara yuridis wajib dilakukan sebelum pemeriksaan pokok perkara, serta apabila tidak dilaksanakan berakibat putusan batal demi hukum (Peraturan Mahkamah Agung Nomor 1 Tahun 2008). Sementara, terhadap proses hakam yang berasal dari masing-masing pihak keluarga, secara yuridis merupakan inisiatif dari majelis hakim untuk melaksanakan (UndangUndang Tentang Peradilan Agama), karena pada pengaturan yang ada dinyatakan dengan frasa "dapat" yaitu berdasarkan putusan sela oleh majelis hakim yang memeriksa, bahkan, dalam praktek, peranan Hakam pada proses perkara perceraian di pengadilan agama tidak lagi relevan dan terlaksana, karena fungsinya telah digantikan oleh mediator sebagaimana diwajibkan oleh Peraturan Mahkamah Agung, serta pihak yang berperkara cenderung sudah bertekad untuk berpisah.
\end{abstract}

Kata Kunci: Hakam, Mediator, Mediasi, Perceraian, Pengadilan Agama.

\section{A. Pendahuluan}

Pengertian dan tujuan perkawinan menurut Undang-Undang Nomor 1 Tahun 1974 tentang Perkawinan adalah "ikatan lahir batin antara seorang pria dengan wanita sebagai suami istri dengan tujuan membentuk keluarga (rumah tangga) yang bahagia dan kekal berdasarkan Ketuhanan Yang Maha Esa". Untuk mencapai hal tersebut, diperlukan adanya saling pengertian dan memahami kepentingan kedua belah pihak, terutama yang terkait dengan hak dan kewajiban. Dalam kehidupan rumah tangga, sering dijumpai suami istri mengeluh dan mengadu kepada orang lain ataupun kepada keluarganya, karena tidak terpenuhinya hak yang harus diperoleh atau tidak dilaksanakannya kewajiban dari salah satu pihak, atau karena alasan lain, yang mengakibatkan timbulnya suatu perselisihan yang berlarut-larut (syiqaq) di antara mereka, yang berakhir dengan perceraian. 
Dalam Al-Qur'an Surat An-Nisa ayat 35, Allah SWT, disebutkan :

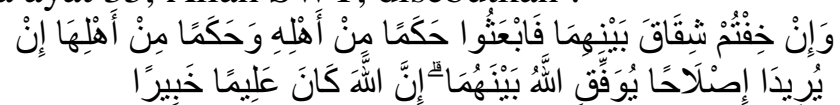

Artinya: Dan jika kamu khawatirkan ada persengketaan antara keduanya, maka kirimlah seorang hakam dari keluarga laki-laki dan seorang hakam dari keluarga perempuan. Jika kedua orang hakam itu bermaksud mengadakan perbaikan, niscaya Allah memberi taufik kepada suami-istri itu. Sesungguhnya Allah Maha Mengetahui lagi Maha Mengenal.

Bahwa jika dikhawatirkan ada persengketaan antara keduanya (suami istri), maka kirimlah seorang hakam, sebagai mediator dari keluarga laki-laki dan dari keluarga perempuan. Dari ayat tersebut, dapat dipahami bahwa salah satu cara menyelesaikan perselisihan/persengketaan antara suami istri, yaitu dengan jalan mengirim seorang hakam selaku "mediator" dari kedua belah pihak untuk membantu menyelesaikan perselisihan tersebut. Penyelesaian damai terhadap sengketa atau konflik sudah ada sejak dahulu. Cara ini dipandang lebih baik dari pada penyelesaian dengan cara kekerasan atau bertanding (contentious). Di Indonesia penyelesaian konflik rumah tangga diselesaikan melalui Badan Penasihatan, Pembinaan dan Pelestarian Perkawinan. Lembaga yang menjadi mitra Departemen Agama yang lahir pada tanggal 3 januari 1960 ini, tidak ada undang-undang yang mengatur secara khusus namun hanya berdasarkan Surat Keputusan Menteri Agama RI Nomor 85 Tahun 1961 yang mengakui Badan Penasihatan, Pembinaan dan Pelestarian Perkawinan adalah satusatunya badan yang berusaha dalam bidang penasehatan perkawinan dan mengurangi perceraian. Suami dan istri yang sedang bersengketa diharapkan menggunakan Badan Penasihatan, Pembinaan dan Pelestarian Perkawinan sebelum mereka mendaftarkan perkaranya di pengadilan. Badan Penasihatan, Pembinaan dan Pelestarian Perkawinan adalah lembaga yang memberikan bimbingan dan penasihatan tentang masalah perkawinan kepada masyarakat (Sayud Margono, 2004).

Memperhatikan tugas-tugas Badan Penasihatan, Pembinaan dan Pelestarian Perkawinan akan diperoleh keterangan seberapa besar peranan badan penasihat ini dalam ikut menangani masalah perkawinan dan perceraian. Badan Penasihatan, Pembinaan dan Pelestarian Perkawinan merupakan satu-satunya lembaga yang akan membantu kesulitan-kesulitan yang berkaitan dengan perkawinan, perselisihan dan perceraian. Setelah usaha yang dilakukan oleh pasangan suami istri untuk mencegah terjadinya perceraian dan orang tua kedua belah pihak dapat menyelesaikan masalah tersebut maka lembaga inilah yang berkompeten untuk dapat menanganinya dan memberikan advokasi dan mediasi. Adapun tugas pokok dari Badan Penasihatan Pembinaan dan Pelestarian Perkawinan, yaitu memberikan bimbingan, penasihatan dan penerangan mengenai nikah, cerai dan talak kepada masyarakat serta memberikan bantuan dalam mengatasi masalah perkawinan, keluarga dan perselisihan rumah tangga. Jadi lembaga ini berusaha untuk memberikan nasehat-nasehat yang baik kepada pasangan yang akan melakukan perkawinan, keluarga yang berselisih maupun yang akan bercerai dengan sebaik-baiknya dan diharapkan akan terbentuk keluarga yang bahagia dan kekal (BP4 Pusat, 1997). Meskipun demikian terdapat perbedaan antara Badan Penasihatan, Pembinaan dan Pelestarian Perkawinan dan lembaga mediasi. Dalam proses penyelesaian sengketa Badan Penasihatan, Pembinaan dan Pelestarian Perkawinan lebih cenderung menasehati dan mendoktrin pasangan rumah tangga yang berkonflik. Peran penasehat di Badan Penasihatan, Pembinaan dan Pelestarian Perkawinan sangat dominan laksana ustad atau kiai yang menasehati santrinya. Berbeda dengan mediasi, dimana mediator hanya sebagai fasilitator, tidak E-ISSN: 2657-0300 Lembaga Penelitian dan Penerbitan Hasil Penelitian Ensiklopedia 201 
boleh menasehati, adil dan tidak memihak. Para pihak sebagai penentu untuk menyelesaikan masalahnya dan mencari solusinya.

Perceraian berdampak terhadap anak-anak dengan hilangnya fungsi-fungsi parenting dari orang tua yang telah berpisah. Untuk mengatasi terjadinya perceraian perlu dilakukan mediasi keluarga yang diarahkan pada upaya membangun pemahaman dan kesepakatan mengenai kelangsungan keluarga. Sejak Tahun 2002 melalui Surat Edaran Mahkamah Agung Nomor 1 Tahun 2002 tentang Pemberdayaan Pengadilan Tingkat Pertama Menerapkan Lembaga Damai. Kemudian pada Tahun 2003 disempurnakan melalui Peraturan Mahkamah Agung Nomor 2 Tahun 2003 tentang Prosedur Mediasi di Pengadilan. Lahirnya cara mediasi melalui Peraturan Mahkamah Agung Nomor 1 Tahun 2008 tentang Prosedur Mediasi di Pengadilan, merupakan penegasan ulang terhadap peraturan sebelumnya yaitu Peraturan Mahkamah Agung Nomor 2 Tahun 2003. Dilatarbelakangi dengan banyaknya perkara di peradilan agama terutama dalam perkara kasasi, mediasi dianggap instrumen efektif dalam proses penyelesaian sengketa yang lebih cepat dan murah serta dapat memberikan akses yang lebih besar kepada para pihak menemukan penyelesaian yang memuaskan dan memenuhi rasa keadilan.

Pasca diberlakukannya Peraturan Mahkamah Agung Nomor 1 Tahun 2008 tentang Prosedur Mediasi di Pengadilan, mediasi telah menjadi salah satu rangkaian penting dari keseluruhan proses penanganan perkara di pengadilan, termasuk Pengadilan Agama. Adanya klausul-klausul yang beraksentuasi imperatif, seperti keharusan melakukan proses mediasi sebelum pemeriksaan pokok perkara, kemungkinan batalnya putusan pengadilan yang tidak menyertakan pertimbangan mediasi, dan berbagai klausul lainnya mendorong perhatian terhadap mediasi menjadi semakin intensif. Pasal 4 Peraturan Mahkamah Agung tersebut, mengisyaratkan bahwa seluruh sengketa perdata yang diajukan ke pengadilan tingkat pertama wajib terlebih dahulu diupayakan penyelesaian damai dengan bantuan mediator kecuali sengketa yang diselesaikan melalui proses pengadilan niaga, pengadilan hubungan industrial, keberatan atas putusan badan penyelesaian sengketa konsumen dan keberatan atas putusan komisi persaingan usaha. Sengketa perdata yang dimaksud dalam pasal ini termasuklah sengketa perkawinan. Selanjutnya Pasal 7 ayat (1) Peraturan Mahkamah Agung Nomor 1 Tahun 2008 telah mewajibkan hakim untuk memerintahkan kepada para pihak yang bersengketa untuk menyelesaikan sengketa tersebut melalui mekanisme mediasi. Selain itu, Pasal 2 ayat (4) dari aturan ini juga mengharuskan hakim memasukkan hasil mediasi ke dalam pertimbangan hukumnya dan menyebutkan mediator untuk perkara yang bersangkutan. Dengan demikian, mediasi sebagai alternatif penyelesaian sengketa di luar persidangan menjadi suatu keharusan dalam penyelesaian sengketa perdata.

Penerapan Peraturan Mahkamah Agung tentang prosedur mediasi dalam proses penyelesaian sengketa perkawinan sejalan dengan Hukum Islam, di mana perceraian adalah suatu perbuatan yang paling dibenci sebagaimana hadis yang diriwayatkan oleh Ibnu Umar ra. : Perbuatan yang halal yang paling dibenci Allah adalah thalaq (cerai). Mediasi ini diterapkan sebagai bagian acara dalam perkara perdata di lingkungan peradilan agama dan peradilan umum. Berdasarkan Pasal 1 angka 7 Peraturan Mahkamah Agung Nomor 1 Tahun 2008 menyatakan bahwa "Mediasi adalah cara penyelesaian sengketa melalui proses perundingan untuk memperoleh kesepakatan para pihak dengan dibantu oleh mediator". Bagi lingkungan Peradilan 
Agama sendiri, kehadiran seorang mediator dalam suatu perkara tampaknya tidak dianggap sebagai sebuah hal yang baru. Pasal 76 Undang-Undang Nomor 7 Tahun 1989 sebagaimana telah diubah beberapa kali terakhir dengan Undang-Undang Nomor 50 Tahun 2009 tentang Perubahan Kedua Atas Undang-Undang Nomor 7 Tahun 1989 tentang Peradilan Agama, telah menetapkan keberadaan hakam dalam perkara perceraian yang eksistensinya sama dengan mediator. Dalam sistem hukum Islam hakam biasanya berfungsi untuk menyelesaikan perselisihan perkawinan yang disebut dengan syiqaq (Nurnaningsih Amriani, 2011). Sebagai pedoman dapat diambil dari Penjelasan Pasal 76 ayat (2) Undang-Undang Nomor 7 Tahun 1989 sebagaimana telah diubah beberapa kali terakhir dengan Undang-Undang Nomor 50 Tahun 2009, dikatakan bahwa "hakam adalah orang yang ditetapkan pengadilan dari pihak keluarga suami atau istri atau pihak lain untuk mencari upaya penyelesaian perselisihan tehadap syiqaq".

Di sisi lain permasalahan akan muncul dalam pemeriksaan perkara perceraian di mana hakam sebagai bagian dari hukum acara sudah dilegitimasi lebih dahulu dari pada mediasi. Mungkinkah keberadaan mediasi yang didasarkan pada Peraturan Mahkamah Agung Nomor 1 Tahun 2008 tetap harus dilaksanakan di samping juga harus memberlakukan hakam yang didasarkan pada Undang-Undang Peradilan Agama? Melihat kenyataan bahwa keberadaan hakam sudah mulai tergeser dengan adanya mediator yang diatur dalam Pasal 1 angka 6 peraturan mahkamah agung ini. Diwajibkannya mediasi khususnya dalam sengketa perkawinan seperti perceraian membawa manfaat yang besar bagi para pihak, karena melalui mediasi akan dicapai kesepakatan dan solusi yang memuaskan dan terselesaikannya problem yang menjadi penyebab keretakan rumah tangga sehingga keutuhan rumah tangga tetap terjaga. Namun perlu diingat, bahwa sengketa perkawinan (perceraian) yang diajukan ke pengadilan tidak jarang saat hari persidangan yang telah ditentukan hanya dihadiri oleh satu pihak saja yaitu pihak Penggugat/Pemohon atau Tergugat/Termohon tidak diketahui alamat pastinya. Di sinilah akan muncul permasalahan, apakah persidangan ditunda untuk memanggil Tergugat/Termohon atau pihak yang tidak hadir sebagaimana Pasal $127 \mathrm{HIR} / 151 \mathrm{RBg}$, atau ditunda untuk mediasi.

Kondisi akan semakin buruk ketika masing-masing pihak tidak memiliki pola komunikasi yang baik, sehingga perselisihan terus semakin meruncing. Semangat untuk berdamai dari masing-masing mungkin saja ada, namun karena tidak mampu menciptakan kesempatan dan peluang untuk itu, akhirnya kesepakatan sulit untuk dicapai. Peran mediator dalam menyelesaikan sengketa akan menjadi penting karena ketidakmampuan para pihak pencari keadilan untuk menciptakan peluang akan difasilitasi oleh mediator dalam sebuah forum komunikasi yang efektif (Yahya Harahap, 2007). Agar fungsi mendamaikan dapat dilakukan hakim lebih efektif, sedapat mungkin dia berusaha menemukan faktor yang melatar belakangi persengketaan. Terutama perkara perceraian atas alasan perselisihan dan pertengkaran, sangat dituntut kemauan dan kebijaksanaan hakim untuk menemukan faktor latar belakang yang menjadi permasalahannya. Karena biasanya perselisihan dan pertengkaran yang muncul hanya permasalahan sepele. Akan tetapi suami istri tidak segera menyelesaikan atau oleh karena suami istri tidak menemukan cara pemecahan yang rasional maka hakim pada pengadilan agama dapat mengangkat Hakam (juru damai). Hakam (juru damai) dipilih dari keluarga suami dan istri, dengan persyaratan jujur dan dapat dipercaya, berpengaruh dan mampu bertindak sebagai juru damai serta orang yang lebih mengetahui keadaan suami istri tersebut sehingga suami istri lebih terbuka mengungkapkan rahasia hati mereka masing-masing. 
Walaupun mediasi yang dilakukan tidak berhasil, akan tetapi mereka sudah mengetahui permasalahan dan mereka pun bisa lebih waspada dan hati-hati dalam menghadapi kehidupan yang penuh dengan perselisihan sehingga kedepannya mereka bisa mengambil hikmahnya. Maka hakim mediator disini sudah melakukan tugasnya untuk mendamaikan kedua belah pihak. Seperti yang dikutip oleh Bambang Sutyoso bahwa Gary Goodpaster menyatakan keberhasilan mediasi terletak pada 3 (tiga) hal, yakni pertama, para pihak mempunyai kekuatan tawar menawar yang sebanding, kedua, para pihak menaruh perhatian terhadap hubungan masa depan, dan ketiga, para pihak tidak memiliki permusuhan (Bambang Sutiyoso, 2008). Mediator juga memiliki peran yang sangat penting dalam menentukan keberhasilan suatu mediasi. Mediator berperan aktif dalam menjembatani sejumlah pertemuan antara para pihak, desain pertemuan, memimpin dan mengendalikan pertemuan, menjaga proses keseimbangan mediasi dan menuntut para pihak mencapai kesepakatan merupakan peran utama yang dimainkan oleh mediator.

Mediator harus mempunyai kemampuan dan keahlian sehubungan dengan bidang atau masalah yang disengketakan. Dalam hal ini yang bertindak sebagai mediator adalah: 1) Jika dalam wilayah Pengadilan yang bersangkutan tidak ada mediator yang bersertifikat, semua hakim pada Pengadilan yang bersangkutan dapat ditempatkan dalam daftar mediator; 2) Mediator bukan hakim yang bersertifikat dapat mengajukan permohonan kepada Ketua Pengadilan agar namanya ditempatkan dalam daftar mediator pada Pengadilan yang bersangkutan; dan 3) Jika pada Pengadilan yang sama tidak terdapat hakim bukan pemeriksa perkara yang bersertifikat, maka hakim pemeriksa pokok perkara dengan atau tanpa sertifikat yang ditunjuk oleh ketua majelis hakim wajib menjalankan fungsi mediator.

Pada akhirnya berjalannya mediasi hingga berhasil memerlukan partisipasi dari para pihak serta mediatornya, juga tidak menutup kemungkinan dari pihak-pihak lain, Akan tetapi tugas pertama yang mendorong mediasi berjalan adalah hakim mediator. Hakim mediator juga harus membantu para pihak untuk memberikan solusi dan keputusan yang terbaik bagi kedua belah pihak. Dalam menjalankan mediasi di pengadilan para Hakim harus mempunyai niat untuk mengembangkan dakwah dalam arti memberikan sebuah pemahaman dan solusi dalam sebuah permasalahan yang dimediasikan, karena kebanyakan orang yang berperkara tidak mengerti terhadap penyebab masalah yang dihadapinya. Oleh karena itu Hakim mediator harus tanggap dan berkompeten dalam menyikapi dan memberikan solusi kepada para pihak sehingga para pihak bisa menerima solusi yang diberikan.

\section{B. Metodologi Penelitian}

Untuk melakukan penelitian ini dan untuk melengkapi bahan-bahan atau data yang konkrit, jawaban yang objektif dan ilmiah serta dapat dipertanggung jawabkan kebenarannya, maka tulisan mengenai korelasi peran hakam (juru damai) dengan mediator dalam proses mediasi perkara perceraian di Pengadilan Agama. Penelitian ini merupakan penelitian deskriptif analitis yang menggambarkan tentang peran deponering dalam perkara pidana di Indonesia. Pendekatan yang digunakan dalam penelitian ini adalah pendekatan yuridis normatif, digunakan untuk mengetahui tentang korelasi peran hakam (juru damai) dengan mediator dalam proses mediasi perkara perceraian di Pengadilan Agama. 


\section{Hasil dan Pembahasan}

Hakam ialah orang yang ditetapkan Pengadilan, dari pihak keluarga suami atau pihak keluarga istri untuk mencari upaya penyelesaian perselisihan terhadap syiqaq. Fungsi hakam terbatas untuk mencari upaya penyelesaian perselisihan, fungsi tersebut tidak dibarengi dengan kewenangan untuk menjatuhkan putusan. Hal ini senada dengan ketentuan Pasal 76 Undang-Undang Nomor 7 Tahun 1989 tentang Peradilan Agama. M. Yahya Harahap (1997) mengutip pendapat Noel J. Coulson memberi sinonim "arbitrator" sebagai kata yang sepadan dengan "Hakam". Begitu juga Morteza Mutahhari mengemukakan kata padanan Hakam dengan "arbiter". Menurutnya hakam dipilih dari keluarga suami dan istri. Satu orang dari pihak keluarga suami dan satu orang dari pihak keluarga istri, dengan persyaratan jujur dan dapat dipercaya, berpengaruh dan mengesankan, mampu bertindak sebagai juru damai serta orang yang lebih mengetahui keadaan suami istri, sehingga suami istri lebih terbuka mengungkapkan rahasia hati mereka masing-masing.

Adapun yang menjadi landasan hukum pemberlakuan hakam dalam bidang perceraian adalah dari Al Quran Surat An-Nisa ayat 35 berbunyi :

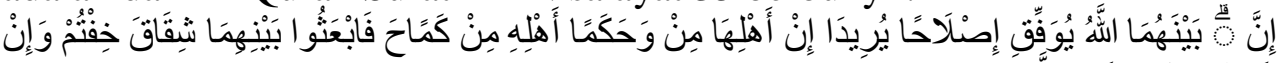

$$
\begin{aligned}
& \text { خَبِيرًا عَلِيمًا كَانَ اللََّ }
\end{aligned}
$$

Artinya: "Kalau kamu ketahui perselisihan antara keduanya suami istri hendaklah kamu utus seorang hakam dari keluarga laki-laki dan seorang hakam dari keluarga perempuan. "

Kalau terjadi perselisihan antara suami istri, hendaklah diadakan seorang hakam dari keluarga suami dan seorang hakam dari keluarga istri. Keduanya berusaha memperdamaikan antara keduanya, sehingga dapat hidup kembali sebagai suami istri. Secara yuridis, pengangkatan seorang hakam pada proses beracara di Peradilan Agama dilakukan setelah didengar keterangan pihak keluarga atau orang-orang dekat dengan para pihak. Hal ini jelas berbeda dengan prosedur mediasi, yang diwajibkan untuk dilalui pleh para pihak yang berperkara, tepat sebelum pemeriksaan pokok perkara berlangsung. Apabila melihat dari sisi peraturan perundang-undangan yang berlaku terkait hakam, setidaknya ada tiga pasal peraturan perundang-undangan yang berbeda yang mengharuskan kehadiran keluarga ataupun kerabat dekat dalam suatu proses persidangan. Ketentuan tersebut terdapat pada: 1) Peraturan Pemerintah Nomor 9 Tahun 1975 tentang Pelaksanaan Undang-Undang Nomor 1 Tahun 1974 tentang Perkawinan; 2) Undang-Undang Nomor 7 Tahun 1989 tentang Peradilan Agama; dan 3) Instruksi Presiden Nomor 1 Tahun 1991 tentang Kompilasi Hukum Islam.

Jika dipersandingkan antara ketentuan hukum positif (Hukum Acara Peradilan Agama) dengan Hukum Islam mengenai keberadaan hakam, akan nampak adanya pergeseran status hukum hakam dalam pandangan hukum Islam dengan hakam yang terdapat pada Undang-Undang Peradilan Agama. Hukum Islam mengharuskan adanya hakam dalam perceraian yang terjadi dengan alasan syiqaq, sementara itu hakam diangkat dari pihak keluarga suami dan istri, sedangkan hakam dalam Undang-Undang Peradilan Agama hanya sebatas anjuran yang tidak mengikat. Status hakam yang bersifat anjuran dan tidak mengikat inilah, yang menjadi pokok perbedaan antara hakam dan mediasi, sebagaimana disinggung sebelumnya. Pada sisi lain hakam dianggap tidak efektif lagi ketika kasus perceraian yang dihadapi oleh hakim ternyata kedua belah pihak telah menyadari bahwa perceraian akan lebih baik dari pada harus mempertahankan rumah tangganya.

Apabila dipahami secara ringkas, mengenai keberadaan mediasi dalam tatanan hukum Indonesia yang berlaku pada hukum acara perdata umum dan perdata agama, E-ISSN: 2657-0300 Lembaga Penelitian dan Penerbitan Hasil Penelitian Ensiklopedia 205 
terlebih dengan keharusan proses mediasi dilakukan sebelum suatu perkara yang bersifat Contentiosa (terdapat sengketa/gugatan) memasuki pemeriksaan pokok perkara, dalam hal ini, merupakan implikasi langsung Peraturan Mahkamah Agung Nomor 1 Tahun 2008 tentang Prosedur Mediasi di Pengadilan. Dikaitkan dengan konsep hakam yang hanya terdapat pada acara peradilan agama, namun dengan catatan, bahwa kehadiran hakam merupakan suatu anjuran/tidak wajib ada. Maka korelasi yang terdapat antara keduanya adalah sama-sama menghendaki penyelesaian perselisihan oleh pihak ketiga. Komparasi dari sudut formil maupun materil, juga akan memberikan gambaran antara keduanya yang pada akhirnya dapat memposisikan secara tepat keberadaan mediasi dalam masalah perceraian. Pemberlakuan tahap mediasi dalam suatu persidangan dilakukan setelah sidang pertama atau sebelum pemeriksaan perkara dilakukan.

Kewajiban hakim mendamaikan para pihak, menjadi pijakan utama mediasi. Pembahasan lembaga damai secara menyeluruh dalam hukum acara, memberikan pengertian bahwa mediasi bukanlah satu-satunya cara untuk mencapai upaya damai. Dimungkinkan pula ketika perkara sudah berlangsung pada tahapan berikutnya (pembuktian misalnya), perdamaian dapat terjadi apabila masing-masing pihak menghendakinya. Mengenai berapa jumlah hakam (juru damai) diatur dalam UndangUndang tentang Peradilan Agama masih tetap mensejajari apa yang dikehendaki AlQuran Surat An-Nisa ayat (35). Jadi mengangkat hakam ( juru damai ) minimal terdiri dari dua orang. Jika masing-masing pihak mempunyai keluarga di tempat terjadinya perkara boleh diangkat satu orang atau lebih. Jika tidak ada keluarganya maka boleh diangkat seorang atau lebih yang bukan pihak keluarga.

Penentuan jumlah hakam (juru damai) lebih dari satu orang sesuai dengan pengertian hukum yang terkandung dalam istilah arbitrator atau arbiter. Fungsi hakam terbatas yaitu untuk mencari upaya penyelesaian perselisihan dan fungsi tersebut tidak dibarengi dengan kewenangan untuk menjatuhkan putusan berarti setelah hakam (juru damai) berupaya mencoba mencari penyelesaian diantara suami istri, fungsi dan kewenangannya berhenti sampai disitu. Hakam (juru damai) mempunyai fungsi kewajiban yang melaporkan kepada Pengadilan sampai sejauh mana usaha yang telah dilakukannya, dan apa hasil yang telah diperolehnya selama hakam (juru damai) menjalankan fungsinya. Hakam hanya sekedar usaha penjajakan penyelesaian perselisihan diantara suami istri tanpa dibarengi dengan kewenangan mengambil putusan.

Pengangkatan hakam (juru damai) dalam perkara perceraian atas dasar syiqaq ialah sesudah proses pemeriksaan perkara melewati tahap pemeriksaan saksi. Berpedoman pada penggarisan tersebut pengadilan dapat mengangkat hakam (juru damai) setelah pemeriksaan pembuktian selesai. Saksi-saksi dan alat bukti lain yang diajukan para pihak sudah selesai diperiksa. Dari hasil pemeriksaan pembuktian Pengadilan telah mendapat gambaran tentang sifat persengketaan yang terjadi antara suami istri kemudian saatnya menunjuk hakam (juru damai). Pengadilan atau Hakim harus terlebih dahulu mengetahui secara seksama apa dan bagaimana perselisihan tersebut dan faktor yang melatar belakangi perselisihan sudah dapat diraba kemudian Hakim memberi bekal kepada hakam (juru damai) tentang segala sesuatu yang ditemukan di persidangan untuk dijadikan sebagai bahan menjajaki usaha penyelesaian perselisihan agar hakam (juru damai) dapat bekerja sebaik mungkin, segala sesuatu yang terjadi di persidangan harus disampaikan kepada Hakim. Kemudian disamping 
penjelasan mengenai hal-hal yang diketemukan di sidang kepada hakam ( juru damai ) diberi: 1) pengarahan seperlunya, 2) saat melaporkan hasil usahanya; dan 3) serta batas jangka waktu penugasan.

Itu sebabnya Hakam (juru damai) yang diangkat orang yang arif, disegani dan mau bekerja serta dapat dipercaya. Hakam (juru damai) benar-benar dikenal dan sangat dekat dengan suami istri dan diberi batas waktu agar penyelesaian perkara tidak terkatung-katung. Apakah mengenai penentuan saat pengangkatan hakam (juru damai) dapat menyimpang dari undang-undang tentang Peradilan Agama? Bisa saja, ketentuan ini tidak bersifat imperatif karena sekiranya dari replik dan duplik Hakim sudah mendapat gambaran yang jelas tentang latar belakang perkara dan berpendapat ada kemungkinan bisa didamaikan melalui hakam (juru damai) yang dekat dan berpengaruh kepada suami istri. Pengangkatan hakam (juru damai) dalam penerapannya yang terbaik adalah dengan cara menyesuaikan dengan ketentuan yang digariskan Undang-Undang Peradilan Agama. Tata cara pengangkatan hakam (juru damai), merupakan kewenangan Ketua Majelis yang memeriksa perkara, walaupun mengenai tata cara pengangkatannya tidak dirinci lebih lanjut. Dengan demikian tata cara pengangkatannya harus berpedoman kepada ketentuan hukum dan sekaligus pula dikaitkan dengan ketentuan hukum acara perdata.

Dari segi pendekatan Hukum Islam maupun dari segi pendekatan hukum acara perdata, pengusulan hakam (juru damai) datang dari pihak-pihak yang berperkara. Para pihak bebas mengusulkan jumlah dan siapa yang mereka inginkan menjadi hakam (juru damai) dari pihaknya, akan tetapi apa yang mereka usulkan tidak mengikat Hakim. Oleh karena itu usul penunjukan hakam (juru damai) yang disampaikan para pihak tidak mutlak mengikat, sebaiknya Hakim menganjurkan kepada pihak para pihak untuk mengusulkan beberapa orang serta dalam pengusulan itu dilengkapi dengan biodata masing-masing calon. Dari keterangan biodata itulah Hakim meneliti satu persatu siapa yang paling tepat diangkat menjadi hakam (juru damai) sesuai dengan persyaratan yang ditentukan Hukum Islam yaitu cakap, jujur, memiliki kapasitas sebagai juru damai, berwibawa dan disegani oleh suami istri. Kemudian Hakim menyuruh datang dan bertemu muka dengan orang-orang yang diusulkan para pihak sebelum mengangkat mereka jadi juru damai. Hal itu ada pemanfaatnya untuk mendapat kesan kepada Hakim apakah orang-orang yang diusulkan para pihak memang tepat diangkat menjadi hakam (juru damai). Sekiranya Hakim berpendapat orang-orang yang diusulkan para pihak kurang tepat maka Hakim dapat mengangkat orang lain. Namun sebaiknya Hakim menanyakan pendapat para pihak dalam melaksanakan pendekatan penyelesaian perselisihan.

Mengenai tata cara pengangkatan yang dianggap sejalan dengan ketentuan hukum acara perdata adalah melalui putusan sela. Dengan demikian pengangkatan hakam (juru damai) ditinjau dari tata tertib beracara berada pada saat pemeriksaan perkara yang berlangsung. Lantas pengangkatan hakam (juru damai) itu sendiri menurut hukum acara perdata adalah tindakan insidentil dari Hakim, sebelum Hakim menjatuhkan putusan akhir. Oleh karena itu pengangkatan hakam merupakan peristiwa insidentil yang terjadi sebelum putusan akhir dijatuhkan, tata cara yang tepat untuk itu adalah dengan putusan sela. Dalam putusan sela tadilah diangkat para hakam (juru damai) serta menyebut tugas apa yang dibebankan Pengadilan kepada mereka, sekaligus dalam putusan sela ditentukan batas jangka waktu tugas hakam (juru damai) serta penundaan pemeriksaan atau penjatuhan putusan akhir, jadi selama masa jangka waktu tugas hakam masih berjalan pemeriksaan perkara ditunda. Ditinjau dari segi pengkajian ilmu fiqih, tidak terdapat kesepakatan yang bulat mengenai pengangkatan 
hakam (juru damai), dalam Undang-Undang tentang Peradilan Agama, pengangkatan hakam (juru damai) sebagai tindakan sunnah atau bukan wajib. Hal itu jelas diatur dalam Pasal 76 ayat (2), menggunakan frasa "dapat" mengangkat hakam. Pengadilan dapat mengangkat hakam (juru damai) apabila proses pemeriksaan saksi sudah dilakukan Pengadilan, yang artinya pengangkatan hakam merupakan tindakan kasuistik yaitu tergantung pada pendapat atau penilaian Hakim. Sekalipun ada permintaan dari salah satu pihak atau dari kedua belah pihak, semuanya tergantung pada pendapat atau penilaian Hakim atas permasalahan mana yang lebih mendatangkan maslahat dalam penyelesaian perkara yang sedang diperiksa. Jika Islah atau damai dapat diperkirakan bisa lebih mudah dicapai melalui hakam (juru damai), kemungkinan pengangkatan hakam ( juru damai ) bisa berubah menjadi wajib.

Prinsipnya Hakim tidak boleh bersikap apriori, dari sejak awal jangan sudah beranggapan tidak bisa dicapai islah. Sikap yang tepat membuka peluang untuk mengangkat hakam (juru damai) sampai putusan dijatuhkan. Sebaliknya, kalau dari hasil pemeriksaan sudah diperoleh gambaran fakta-fakta yang sangat parah dan pengangkatan hakam sudah diperhitungkan akan sia-sia. Hakim lebih tepat menyelesaikan pemeriksaan perkara kemudian Hakim dapat berpegang pada sunnatullah, bahwa tidak semua yang rusak dan pecah bisa dipulihkan. Kalau pecahnya sudah sedemikian rupa parahnya tidak layak untuk membuang waktu mengangkat hakam (juru damai), maka berkaitan dengan pengangkatan hakam (juru damai) mengambil sikap moderasi antara sunnah dan wajib. Tidak selalu cenderung pada prinsip sunnah dan juga jangan menjadi terlalu prinsip menerapkannya dalam acuan wajib. Kedua patokan hukum tersebut dapat dipedomani Hakim sesuai dengan kondisi dan hasil pemeriksaan, cara bertindak yang demikian tidak bertentangan dengan ketentuan Undang-Undang Peradilan Agama dan surat An-Nisa ayat (35).

Undang-Undang Peradilan Agama sendiri tidak menyinggung sampai dimana kekuatan mengikat pendapat atau usul hakam kepada Hakim dalam menjatuhkan putusan. Barangkali hal itu sesuai dengan fungsi hakam yang tidak dibarengi dengan kewenangan apapun. Sebagaimana yang sudah disinggung undang-undang tidak memberi kewenangan bagi hakam untuk menjatuhkan putusan. Hakam wajib berusaha untuk mencari upaya penyelesaian tapi tidak berwenang memutus dan menyelesaikan sendiri perselisihan suami istri, yang ada hukum memberi hak mengusulkan atau mengajukan pendapat kepada Hakim yang mengangkatnya. Usul atau pendapat yang diajukannya sama sekali tidak mengikat kepada Hakim, undang-undang memberi kebebasan sepenuhnya kepada Hakim untuk menilai apakah dia akan menerima atau tidak apa yang diusulkan hakam.

Berbeda dengan mediasi, hakam diterapkan setelah proses pembuktian berlangsung yaitu setelahnya hakim mendengar pihak keluarga atau orang-orang dekat dengan pihak suami istri. Pengangkatan hakam dituangkan dalam putusan sela, sedangkan mediator dapat saja dilakukan dengan cara pemberitahuan oleh Ketua Majelis. Dari sudut pandang materiil, mediasi pada awalnya dihadapkan dalam perkara bisnis meskipun dalam perkembangan berikutnya juga diberlakukan dalam hukum keluarga. Oleh karenanya wajar apabila dikatakan, tidak ada mediasi tanpa negosiasi, karena mediasi mengedepankan bargaining position dengan memberikan tawaran nilai dari masing-masing pihak. Adapun hakam, merupakan salah satu bagian dari hukum perkawinan mengenai perceraian dengan alasan syiqaq. Tidak ada yang ditawarkan dalam bentuk nilai maupun materi lainnya dalam proses hakam tersebut. Hakam hanya 
berupaya meneliti dan menelaah serta menilai sifat dan bentuk dari perselisihan yang terjadi antara suami istri. Dengan melihat perkembangan hukum perkawinan di Indonesia ternyata perkara perceraian sering kali diajukan ke Pengadilan Agama dalam bentuk kumulasi dengan perkara lainnya seperti tuntutan nafkah terutang, mut'ah, nafkaah iddah, pemeliharaan anak, nafkah anak ataupun harta bersama. Dengan adanya kumulasi tersebut, perkara perceraian yang sebelumnya hanya menyangkut permasalahan rumah tangga saja kemudian berkembang menyangkut masalah nilai dan materi. Pada saat seperti inilah keberadaan mediator sangat diperlukan untuk memfasilitasi upaya bargaining tawar menawar maupun negosiasi mengenai tuntutantuntuan yang diajukan oleh penggugat. Demikian halnya dengan hakam, setelah proses perceraian berlangsung dan pihak keluarga telah didengar, dengan melihat bentuk perselisihannya hakim dapat mengangkat hakam untuk menyelesaikan syiqaqnya.

Menurut penulis tidak ada duplikasi proses hukum, karena substansi mediasi dan hakam memang berbeda, mediasi lebih ditekankan pada penyelesaian permasalahan yang bersifat materi (meskipun juga dalam bidang perceraiannya), sedangkan hakam hanya menyelesaikan masalah perceraian. Penerapan mediasi dan hakam seperti di atas akan sangat berbeda ketika dihadapkan dengan perkara perceraian tanpa kumulasi dengan perkara lainnya. Memberlakukan mediasi dan hakam secara bersamaan dalam perkara perceraian (tanpa kumulasi) dari satu sisi, hakim dipandang telah memberlakukan prosedur acara yang sama dalam waktu yang berbeda (mediasi sebelum pemeriksaan perkara, hakam dalam proses perkara), karena keduanya samasama memberikan fasilitas kepada para pihak untuk mencari jalan damai. Di sisi lain pemberlakuan mediasi dan hakam dalam perkara seperti ini hanya akan menambah waktu dan biaya serta menghilangkan nilai filosofis dari Peraturan Mahkamah Agung yang terkandung dalam konsiderannya untuk penyelesaian sengketa yang lebih cepat dan murah, serta dapat memberikan akses yang lebih besar kepada para pihak menemukan penyelesaian yang memuaskan dan memenuhi rasa keadilan.

\section{D.Penutup}

Dari berbagai uraian dalam pembahasan yang telah diuraikan sebelumnya, dapat ditarik kesimpulan sebagai beriku, bahwa pada prinsipnya hakam dan mediator berbeda, dalam hal ini, mediasi yang dilakukan oleh mediator secara yuridis wajib dilakukan sebelum pemeriksaan pokok perkara, serta apabila tidak dilaksanakan berakibat putusan batal demi hukum (Peraturan Mahkamah Agung Nomor 1 Tahun 2008). Sementara, terhadap proses hakam yang berasal dari masing-masing pihak keluarga, secara yuridis merupakan inisiatif dari majelis hakim untuk melaksanakan (Undang-Undang Tentang Peradilan Agama), karena pada pengaturan yang ada dinyatakan dengan frasa "dapat" yaitu berdasarkan putusan sela oleh majelis hakim yang memeriksa, bahkan, dalam praktek, peranan Hakam pada proses perkara perceraian di pengadilan agama tidak lagi relevan dan terlaksana, karena fungsinya telah digantikan oleh mediator sebagaimana diwajibkan oleh Peraturan Mahkamah Agung, serta pihak yang berperkara cenderung sudah bertekad untuk berpisah.

\section{Daftar Pustaka}

A. Hamid Sarong, 2005, Hukum Perkawinan Islam di Indonesia, Banda Aceh: Yayasan Pena Divisi Penerbitan.

Abdul Manan, 2001, Penerapan Hukum Acara di Lingkungan Peradilan Agama, Jakarta, Yayasan Al Hikmah.

Achmad Kuzari, 1995, Nikah Sebagai Perikatan, Jakarta: PT. RajaGrafindo Persada. 
Bambang Sutiyoso, 2008, Alternatif Penyelesaian Sengketa, Yogyakarta: Gama Media.

D. Y. Witanto, 2011, Hukum Acara Mediasi Dalam Perkara Perdata di Lingkungan Peradilan Umum dan Peradilan Agama Menurut PERMA Nomor. 1 Tahun 2008 tentang Prosedur Mediasi di Pengadilan, Bandung : Alfabeta.

Djamil Latif, 1982, Aneka Hukum Perceraian di Indonesia, Jakarta: Ghalia Indonesia.

Kamal Mukhtar, 2002, Asas-asas Hukum Islam Tentang Perkawinan, Jakarta: Bulan Bintang.

Kementerian Agama RI, 2010, Al-Qur'anulkarim, Syamil Al-Qur'an Miracle The Reference, 22 Keunggulan yang Memudahkan dalam 1 Al-Qur'an dengan Referensi yang Sahih, Lengkap dan Komprehensif, Bandung: PT Sygma Examedia Arkanleema.

Khoirudin Nasution, 2005, Hukum Perkawinan I : Dilengkapi Perbandingan UU Negara Muslim Kontemporer, Yogyakarta: Academia \& Tazzafa.

Lalu Husni, 2005, Penyelesaian Perselisihan Hubungan Industrial Melalui Pengadilan \& di Luar Pengadilan, Jakarta: PT. Raja Grafindo Persada.

Mas Achmad Santosa dan Wiwik Awiati, 2003, Mediasi dan Perdamaian, Mahkamah Agung RI.

M. Faiz Mufidi, Analisis Terhadap Metoda-Metoda Alternatif Penyelesaian Sengketa Menurut Undang- Undang Nomor 30 Tahun 1999 Tentang Arbitrase Dan Alternatif Penyelesaian Sengketa, dalam Syiar Madani Jurnal Hukum, Volume VII Nomor 3, Nopember 2005.

$\mathrm{Nj}$. Aisjah Dachlan, 1996, Membina Rumah Tangga Bahagia dan Peranan Agama Islam dalam Rumah Tangga, Jakarta: Jamunu.

Nurnaningsih Amriani, 2011, Mediasi Alternatif Penyelesaian Sengketa Perdata di Pengadilan, Divisi Buku Perguruan Tinggi, Jakarta: PT Raja Grafindo Persada.

Muhammad Yunus, 1956, Hukum Perkawinan menurut Madzhab Syafi'I, Hanafi, Malaiki, dan Hambali, Jakarta: Hadakarya Agung,

Syahrizal Abbas, 2011, Mediasi Dalam Hukum Syariah, Hukum Adat dan Hukum Nasional, Jakarta: Kencana Prenada Media Group,.

Wahyu Widiana, Upaya Penyelesaian Perkara Melalui Perdamaian di Pengadilan Agama, Kaitannya dengan BP4, Makalah disampaikan pada Rakernas BP4 tanggal 15 Agustus 2008 di Jakarta.

Yahya Harahap, 2007, Hukum Acara Perdata Tentang Gugatan, Persidangan, Penyitaan, Pembuktian Putusan Pengadilan, Jakarta: Sinar Grafika. 